\title{
Spectroscopic and chemical analysis of burnt earth under Amazonian homegarden systems and anthropic Amazonian dark soils
}

\author{
Newton P. S. Falcão ${ }^{1}$, Eluise S. Lopes ${ }^{2}$, Erlon H. M. Ferreira ${ }^{2}$, Danielle M. Oliveira ${ }^{1}$, Braulio S. \\ Archanjo $^{2}$, Carlos A. Achete ${ }^{2}$ and Joyce R. Araujo ${ }^{2 \star}$ \\ ${ }^{1}$ Coordenação de Tecnologia e Inovação, Instituto Nacional de Pesquisas da Amazônia, Manaus, AM 69011-970, \\ Brazil. \\ ${ }^{2}$ Instituto Nacional de Metrologia, Qualidade e Tecnologia, Av. Nossa Sra. das Graças, 50, 25250-020 Duque de \\ Caxias, RJ, Brazil.
}

Accepted 17 December, 2018

\begin{abstract}
The practice of burning organic residues is locally known, in Amazon basin, as burnt earth (Terra Queimada). Among burnt earth soils, there are differences on their origins, as earth soils from Oxisol and Ultisol soil profiles. To understand the main physical and chemical attributes responsible for the improvement of the fertility of these soils, spectroscopic and elemental analyses were performed at four different sites: three in an Oxisol profile and one in an Ultisol profile, both collected in Amazonas State, Brazil. The burnt earth soil exhibited improved fertility indices compared with a sample from Yellow Oxisol within a secondary forest profile. The major differences were a higher $\mathrm{pH}$ value and increased $\mathrm{C}, \mathrm{N}$, available $\mathrm{P}$, exchangeable $\mathrm{Ca}, \mathrm{Mg}$ and $\mathrm{K}$ contents. An anthropic Amazonian Dark soil was investigated for comparison with burnt earth soils and showed intermediate values in relation to the other two studied samples for the most of the chemical attributes as $\mathrm{pH}$, total base cations and effective cation exchange capacity. The lower fertility of the Yellow Oxisol under secondary forest sample can be explained by the high content of $\mathrm{Al}^{3+}$ and $\mathrm{H}^{+}$cations that directly impact its potential cation exchange capacity. Fourier-transform infrared spectroscopy and X-ray photoelectron spectroscopy revealed the presence of calcium in different forms, being these important in the correction of the soil acidity. In addition, Raman spectroscopy indicated that burnt earth contains carbon with crystallite sizes that are typical of structures within the limit region between nanographite and amorphous carbons.
\end{abstract}

Keywords: Amazonian dark earth, homegarden, burnt earth, x-ray photoelectron spectroscopy, Fouriertransform infrared spectroscopy, Raman spectroscopy.

${ }^{*}$ Corresponding author. E-mail: jraraujo@inmetro.gov.br. Tel: +55 2126799021. Fax: +55 2126799597.

\section{INTRODUCTION}

Homegardens have been described as small-scale agricultural production formed by stratified agroforestry systems that are ecologically and socially sustainable (Fernandes and Nair, 1986; Weersum, 1982). These systems aim to produce food, fiber, medicinal plants and construction materials, most of which are produced for subsistence (Gibbon, 2007). Numerous studies of homegardens have focused on their high agrobiodiversity
(Miller et al., 2006) and their role in conserving such biodiversity (Fernandes and Nair, 1986; Griffith, 2000; Montagnini, 2006), but it is not well understood how the soil management of these gardens is achieved (Sánchez, 1976). Recent studies on Amazonian homegardens reported a soil management process locally known as Terra Queimada (TQ) or 'burnt earth' (WinklerPrins, 2002; WinklerPrins and Souza, 2005). This practice 
involves the frequent sweep of homegarden organic debris, such as leaves, branches, seeds, peelings of fruit and roots (70 to $80 \%$ ), household wastes as animal bones after meat consumption (10 to $15 \%$ ), and soil surface sweepings (5 to $10 \%$ ), to the backyard where everything is burned in a slow combustion process (smoldering). Steiner (2009) reported high fertility of the burned earth managed in the indigenous habitation site of Amazonian. Falcão et al. (2010) concluded that presentday soils management in Homegardens, particularly the creation of $T Q$, was used by indigenous people to initially form ADEs. TQ is the product of the biocarbonization of household organic waste, hence a type of biochar. This process is normally developed on soils classified as Ferrasols (FAO, 1994) or Distrophic Yellow Oxisols (EMBRAPA, 2006).

Biocarbonization process is performed using low intensity burning similar to smoldering, a type of combustion in which no flame is produced (Lilley, 1999). Different carbonization temperatures may be present depending of the height and width of the organic waste piles. Through field observations, the temperature of the pile surface is expected to be greater than $500^{\circ} \mathrm{C}$, producing large amounts of ash. In the intermediate and bottom portions of the pile, temperatures are lower $(200$ to $500^{\circ} \mathrm{C}$ ) due to the lower oxygen availability, producing large amounts of pyrogenic carbon. As a result of this process, pyrogenic carbon is produced by thermal decomposition of biomass under limited or no oxygen, and could be applied as a soil conditioner to increase fertility or to sequester atmospheric $\mathrm{CO}_{2}$ (Doumer et al., 2015). Ashes, from the biocarbonization of organic waste, contain large amounts of $\mathrm{Ca}, \mathrm{Mg}$ and $\mathrm{K}$ that can react with negatively charged carbon functional groups of pyrogenic carbon, increasing soil CEC (cation exchange capacity). The combination of ash and pyrogenic carbon provides mineral nutrients that are important for plant nutrition (Antal and Grønli, 2003; Turney et al., 2006). The pyrogenic carbon is frequently referred also as biochar or black carbon (Klüpfel et al., 2014). Pyrogenic carbon or black carbon are stable charcoal particles founded in highly fertile anthropogenic soils, as Amazonian Dark (AD) soils, known also as "Terra Preta de Índios", localized in the Amazonian basin (Pagano et al., 2016), made of $\mathrm{sp}^{2}$-ordered carbon nanocrystallites with lateral dimensions of $\sim 3$ to $8 \mathrm{~nm}$ (Jorio et al., 2012; Ribeiro-Soares et al., 2013; Glaser et al., 2004; Denevan, 2004; Neves et al., 2004).

Spectroscopic techniques applied to the soil analysis afford simultaneously characterize soil organic matter (SOM) and soil minerals compositional chemistry, and the interactions between these two phases as well. Recently, advanced spectroscopic techniques have been used to study $A D$ soil properties and determine the chemical structures of SOM that are responsible for the recalcitrance and reactivity of these highly fertile soils (Araujo et al., 2014; Archanjo et al., 2014; Archanjo et al.,
2015; Jorio et al., 2012; Ribeiro-Soares et al., 2013).

The aim of the present work is to better understand how the TQs may increase the fertility of the $A D$ surrounding soils and even maintain the fertility of the $A D$ soils. To this end, classical soil chemical analysis, that are used to evaluate the soil properties, were combined with various advanced tools and techniques used in the field of materials science, such as X-ray photoelectron spectroscopy (XPS), Raman Spectroscopy and Fouriertransformed infrared spectroscopy (FTIR).

\section{MATERIALS AND METHODS}

\section{Sites and sampling}

Four sites were selected for soil sampling. Three sites are located in Costa do Laranjal, Manacapuru (Lat. 3 17' S, Long. 60²9' W), altitude $76.177 \mathrm{~m}$ at $60 \mathrm{~km}$ from Manaus, Amazonas State, Brazil, (Figure 1a). The first sample was collected in Yellow Oxisol with an anthropic A horizon under rubber plantation, named here as "Terra Preta de Índio do Seringal' (TPS). The second sample was collected in a dystrophic Yellow Oxisol within a secondary forest, named here as "Latossolo Amarelo Distrófico sob Floresta" (LAF). The third sample was collected in dystrophic Yellow Red Ultisol within homegardens, locally named "Terra Queimada da Costa doLaranjal' (TQCL). The fourth sample was collected in Yellow Oxisol within homegardens in Rio Preto da Eva (Lat. $2^{\circ} 37^{\prime} \mathrm{S}$, Long. $59^{\circ} 40^{\prime} \mathrm{W}$ ), altitude $38.157 \mathrm{~m}$ at $80 \mathrm{~km}$ from Manaus, Amazonas State Brazil, which is locally named "Terra Queimada do Ramal do Banco" (TQRB) (Figure 1a). The studied soils were classified as dystrophic Yellow Oxisol and dystrophic Yellow Red Ultisol according to Brazilian System of Soil Classification (EMBRAPA, 2006) and Soil Taxonomy (Baillie, 2001). The regional climate is classified as Af in the Köppen system and is typical of the tropical rainforest with an average annual temperature of $26^{\circ} \mathrm{C}$ and annual rainfall of $2450 \mathrm{~mm}$. The dry season typically occurs from July through December. The average daily temperature is $26^{\circ} \mathrm{C}$ and the average annual precipitation is just under $2000 \mathrm{~mm}$ (Ratisbona 1976).

\section{Soil sampling and chemical analysis}

Five points, within a $30 \mathrm{~m}$ diameter circular area, were selected for sampling LAF and TPS soil composition, using a Dutch auger, as shown in Figure 1b. Four points were chosen in the site boundaries, and one point was selected in the central area. The samples were obtained from $0 \mathrm{~cm}$ to $20 \mathrm{~cm}$ after removing a thin superficial layer of litter $(0$ to $10 \mathrm{~cm})$. Both burnt earth samples, TQCL and TQRB, were collected in three different points within a 4 to $6 \mathrm{~m}$ diameter circular area.

Samples were dried at environment temperature $\left(40^{\circ} \mathrm{C}\right)$ for $72 \mathrm{~h}$ and then passed through a $2 \mathrm{~mm}$ sieve (EMBRAPA, 1999). The soil was analyzed at the Plant Laboratory of the National Institute for Amazonian Research (INPA) to determine the chemical attributes important to the soil fertility. Total carbon $(\mathrm{C})$ and nitrogen $(\mathrm{N})$ were measured by the dry combustion methodology (Nelson and Sommers, 1996) using an elementar Vario MAX CN. Extractable levels of potassium $(\mathrm{K})$, calcium $(\mathrm{Ca})$, magnesium $(\mathrm{Mg})$ phosphorus $(\mathrm{P})$, iron $(\mathrm{Fe})$, manganese $(\mathrm{Mn})$, and zinc $(\mathrm{Zn})$ were determined using the Mehlich 1 extraction method $\left(\mathrm{HCl} 0.05 \mathrm{~mol} \mathrm{~L}^{-1}+\mathrm{H}_{2} \mathrm{SO}_{4}\right.$ $0.0125 \mathrm{~mol} \mathrm{~L}^{-1}$ ) (Kuo, 1996), and available $\mathrm{P}$ was determined colorimetrically via ammonium molybdate and the ascorbic acid method (Falcão and Silva, 2004) using an UVmini-1240 UV-Vis 

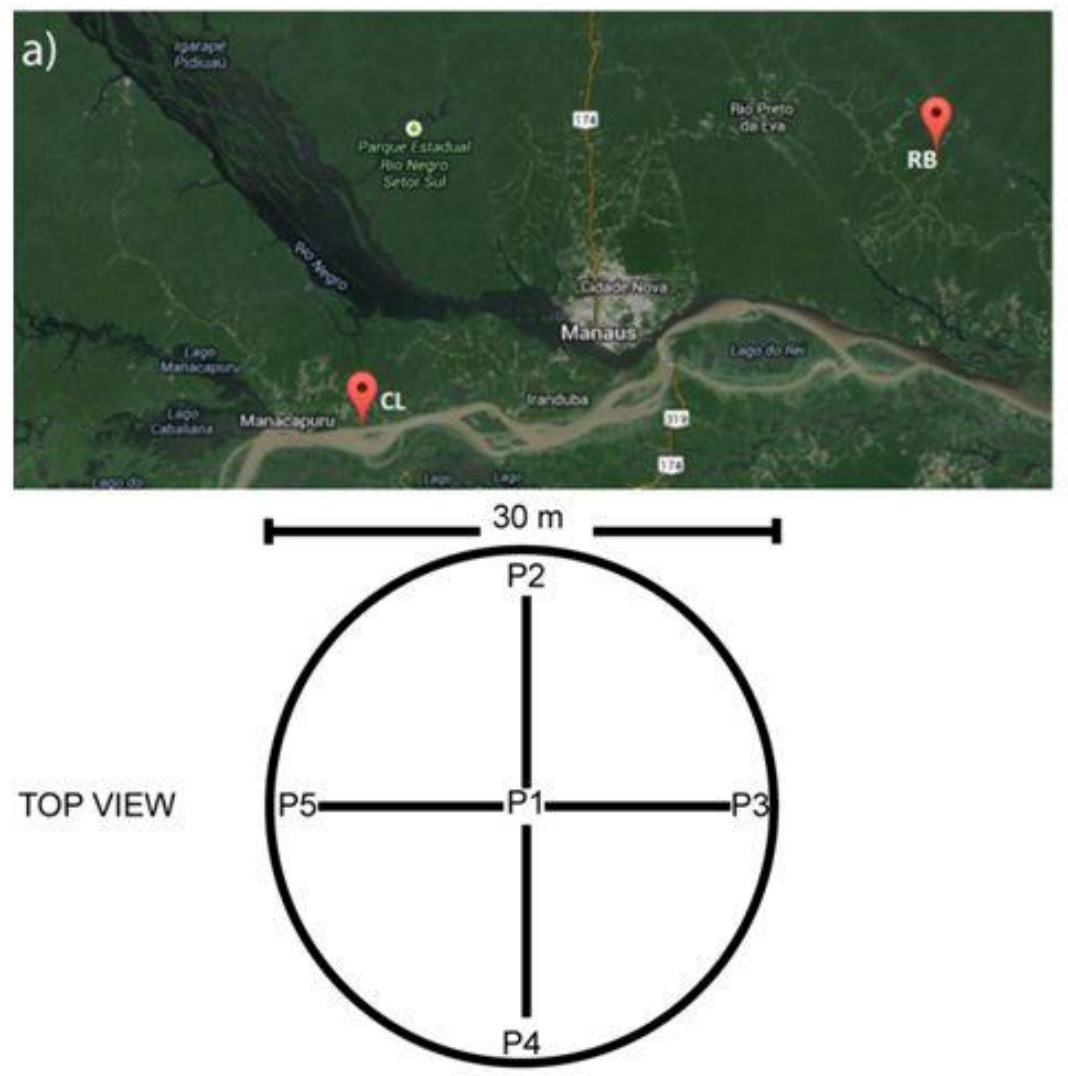

Pile Surface Temperature $>500^{\circ} \mathrm{C}$

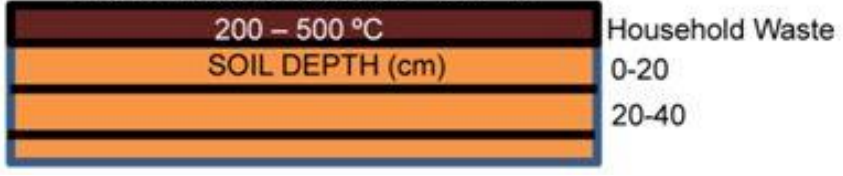

Figure 1. a) Map of the cities and areas, localized in the Amazonian state, Brazil, where the four soil samples were collected. b) Design of a circular area $30.0 \mathrm{~m}$ in diameter used as a model where AD and Oxisol under secondary forest soils samples were collected.

Spectrophotometer. K, Ca, Mg, Fe, Mn and $\mathrm{Zn}$ levels were determined by atomic absorption using a Thermo Scientific iCE 3000 Atomic Absorption Spectrometer. Exchangeable aluminum was determined by titration with $1 \mathrm{~mol} \mathrm{~L}^{-1}$ of $\mathrm{KCl}$ and $0.025 \mathrm{~mol} \mathrm{~L}^{-1}$ of $\mathrm{NaOH}$. The soil $\mathrm{pH}$ was determined in deionized water (1:2.5 soil:solution ratio) using an electronic $\mathrm{pH}$ meter with a glass electrode (EMBRAPA, 1999). All soil fertility data were tabulated and analyzed using the statistic program "R" from the Development Core Team (2008). Initially, an analysis of variance was performed, and the data that were validated by an $F$ test underwent the average test (Tukey, $5 \%$ ).

\section{Spectroscopic characterization}

The functional groups and inorganic substances in $A D$ and $T Q$ samples were analyzed by FTIR in a Perkin-Elmer Spectrum GX spectrometer using the potassium bromide $(\mathrm{KBr})$ transmission technique. XPS spectra were measured to evaluate the elemental composition and the chemical groups present in the samples. The analysis was performed using an Escaplus $P$ System (Omicron Nanotechnology; Taunusstein, Germany). The system operates in an ultra-high vacuum (base pressure $=10^{-10} \mathrm{mbar}$ ) using an $\mathrm{Mg}$ (Ka $=1253.6 \mathrm{eV}$ ) X-ray source, and power is provided by an emission current of $16 \mathrm{~mA}$ at a voltage of $12.5 \mathrm{kV}$. Raman spectra were acquired using a Renishaw InVia spectrometer with a $2.41 \mathrm{eV}$ excitation light (514.5 $\mathrm{nm}$ line from an Argon-Krypton laser) in a backscattering geometry. The laser power density was maintained under $15 \mathrm{~W} / \mathrm{mm}^{2}(100 \mu \mathrm{W} @ 20 x$ objective/N.A 0.40$)$ to avoid sample heating and local graphitization.

\section{RESULTS AND DISCUSSION}

\section{Visual diagnosis}

Visual diagnosis (Figure 2) shows remarkable differences between LAF (Figure 2a and d), TQRB (Figure $2 b$ and e) and TPS sites (Figure $2 c$ and f). While LAF was not visibly anthropogenically influenced (Figure $2 \mathrm{a}$ and d), TQRB soil picture (Figure $2 \mathrm{~b}$ and e) revealed that the first layer was strongly influenced by the input of pyrogenic 

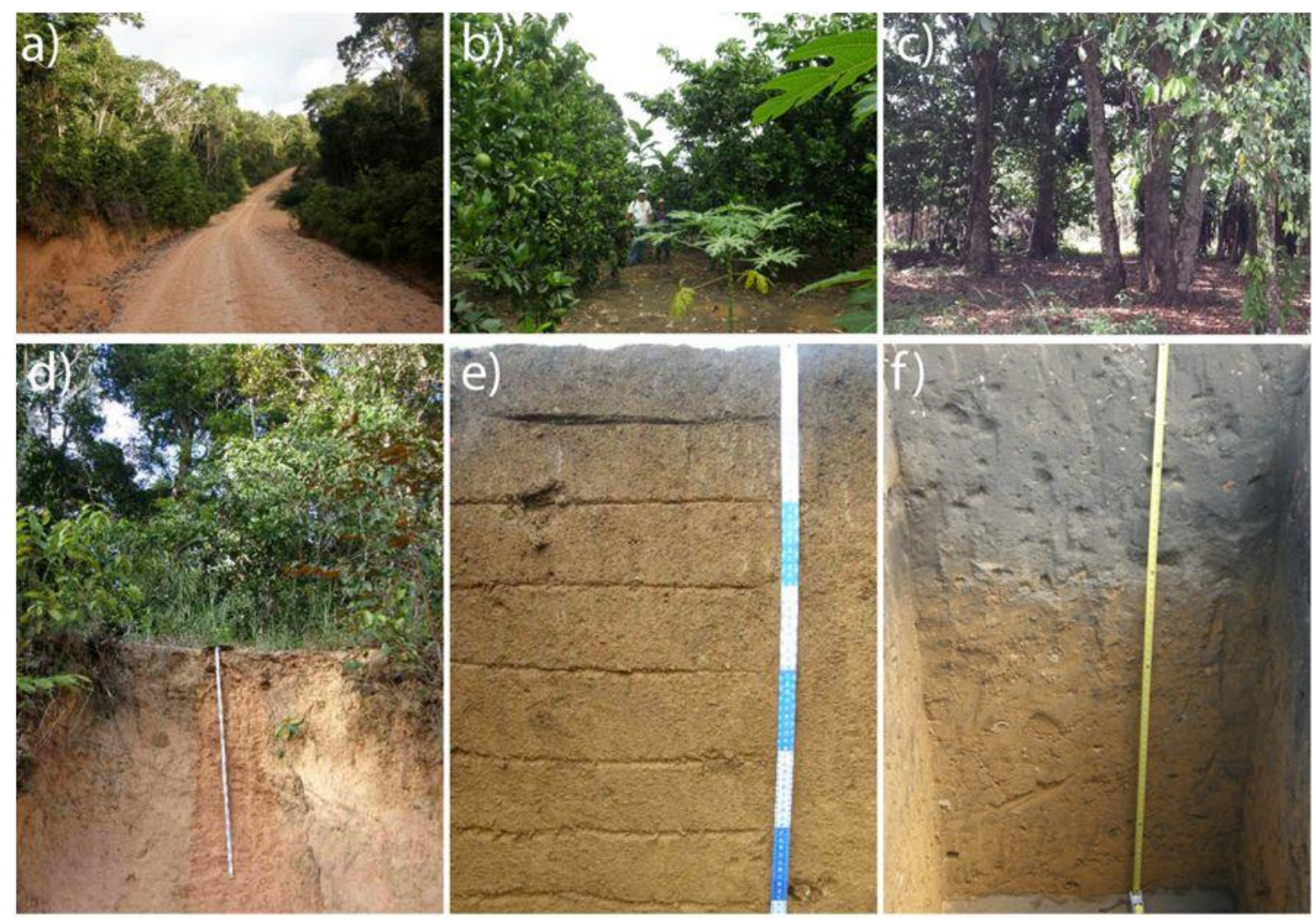

Figure 2. Visual diagnosis and soil horizon pictures of three different soils studied, where: (a), (d) YellowOxisol within a secondary forest (LAF), (b), (e) Yellow Oxisol within homegardens (TQRB), (c), (f)Yellow Oxisol with an anthropic $A$ horizon under rubber plantation (TPS).

carbon due to slow pyrolysis of animal and vegetable organic residues that were deposited for a long period. TPS (AD site) showed deeper black layers due to the high amounts of black carbon. The main chemical properties as well as the elemental analysis of soils in the landscape of Manacapuru and Rio Preto da Eva cities are presented in Tables 1 and 2. The inclusion of these elements in our analyzes is due to the fact that it is important to know, in qualitative and quantitative terms, all the macro and micronutrients that are present and readily available for the plant growth in the regions of the burned earth soil condition. In addition, small content of micronutrients, such as $\mathrm{Zn}$ and $\mathrm{Mn}$ may limit the plant growth process, so the presence of these nutrients in the burned earth is very important for improving the soil fertility. Therefore, it is essential to detect the presence and quantity of these macro and micronutrients in these managed soils.

\section{Soil reaction}

Soil acidity, expressed by its $\mathrm{pH}$ value, is an important variable that affects the physical, chemical and biological soil properties and is responsible for the control of the nutrients availability for plant nutrition and microbial reactions (Brady and Weil, 1999; Havlin et al., 2013; Van Alfen, 2014). The average test (Tukey, $5 \%$ ) demonstrated that not only active acidity, which is expressed as $\mathrm{pH}$ in water, but also the exchangeable acidity (exchangeable aluminum) and the potential acidity (hydrogen plus aluminum) presented large and highly significant differences in Oxisol under a Secondary Forest sample (LAF) in comparison with the other three studied samples (Table 3).

High contents of $\mathrm{Al}^{3+}$ and $\mathrm{H}^{+}+\mathrm{Al}^{3+}$ found in LAF may be related with high chemical and biological degradation of organic matter by soil microbial communities inhabiting this soil. These cations result in $\mathrm{CO}_{2}$ release, which in turns can react with water to produce $\mathrm{HCO}_{3}$ and $\mathrm{H}^{+}$, increasing the soil acidity. In addition, soil organic matter contains carboxylic and phenolic groups that act as weak acids, releasing $\mathrm{H}^{+}$and increasing the soil acidity (Havlin et al., 2013). With respect to aluminum concentration in LAF, the high rainfall and acidity of the Amazonian forest soils accelerate the weathering of rocks that contains aluminosilicates, clays, aluminum salts, iron and aluminum oxides and hydroxides, releasing large amounts of $\mathrm{Al}^{3+}$ ion to the soil (Brady and Weil, 1999; Havlin et al., 2013; Malavolta, 1976).

Increased $\mathrm{pH}_{(\mathrm{H} 2 \mathrm{O})}$ values $(7.38)$ as well as reduced exchangeable acidity $\left(\mathrm{Al}^{3+}, 0.01\right)$ and potential acidity 
Table 1. Chemical properties of predominant soils of the Rio Preto da Eva (Oxisol) and Manacapuru (Ultisol) municipalities.

\begin{tabular}{|c|c|c|c|c|c|c|c|c|c|c|}
\hline \multirow{2}{*}{ Soils } & $\mathrm{pH}$ & $\mathrm{Ca}^{2+}$ & $\mathrm{Mg}^{2+}$ & $\mathrm{K}^{+}$ & $\mathrm{Al}^{3+}$ & $\mathrm{H}^{+}+\mathrm{Al}^{3+}$ & $\mathbf{P}$ & $\mathrm{Fe}$ & $\mathrm{Zn}$ & Mn \\
\hline & $\left(\mathrm{H}_{2} \mathrm{O}\right)$ & \multicolumn{5}{|c|}{ cmolc kg- $^{1}$} & \multicolumn{4}{|c|}{$\mathrm{mg} \mathrm{kg}^{-1}$} \\
\hline Or & 5.19 & 0.09 & 0.08 & 0.03 & 2.92 & 10.43 & 2.70 & 355.53 & 0.09 & 0.39 \\
\hline Ultisol & 4.93 & 0.09 & 0.07 & 0.02 & 1.65 & 7.20 & 2.11 & 233.15 & 0.26 & 0.20 \\
\hline
\end{tabular}

Table 2. Chemical properties of predominant soils of the Rio Preto da Eva (Oxisol) and Manacapuru (Ultisol) municipalities.

\begin{tabular}{|c|c|c|c|c|c|c|c|c|}
\hline \multirow{2}{*}{ Soils } & C & $\mathbf{N}$ & \multirow{2}{*}{$\mathrm{C} / \mathrm{N}$} & \multirow{2}{*}{\multicolumn{3}{|c|}{$\frac{\mathrm{t}^{(\mathrm{b})}}{\mathrm{cmolc} \mathrm{kg}^{-1}}$}} & $\mathbf{m}^{(\mathrm{d})}$ & $\mathbf{V}^{(\mathrm{e})}$ \\
\hline & & & & & & & \multicolumn{2}{|c|}{$\%$} \\
\hline Oxisol & 17.65 & 1.15 & 15.36 & 0.20 & 3.12 & 10.63 & 93.48 & 6.52 \\
\hline Ultisol & 15.85 & 1.15 & 13.66 & 0.18 & 1.83 & 7.38 & 90.31 & 9.69 \\
\hline
\end{tabular}

${ }^{\mathrm{a}} \mathrm{SB}$ : total base cations $(\mathrm{K}, \mathrm{C}$ and $\mathrm{Mg}) .{ }^{\mathrm{b}} \mathrm{t}$ : effective cation exchange capacity (sum of $\mathrm{K}^{+}, \mathrm{Ca}^{++}, \mathrm{Mg}^{++}$and $\mathrm{Al}^{+++}$). ${ }^{\mathrm{c}} \mathrm{T}$ : potential cation exchange capacity (sum of $\mathrm{K}^{+}, \mathrm{Ca}^{++}, \mathrm{Mg}++, \mathrm{Al}^{+++}$and $\mathrm{H}^{+}+\mathrm{Al}^{+++}$). ${ }^{d} \mathrm{~m}$ : Al saturation percentage for effective cation exchange capacity. ${ }^{\circ} \mathrm{V}$ : base saturation percentage for effective cation exchange capacity.

Table 3. Soil chemical attributes sampled from a 0- to 20-cm depth of the of Ramal do Banco Burnt Earth (TQRB), Laranjal Cost Burnt Earth (TQCL), Oxisol under forest (LAF) and Amazonian Dark Earth under Rubber Plantation (TPS) (N=5).

\begin{tabular}{|c|c|c|c|c|c|c|}
\hline \multirow{3}{*}{ Site } & \multicolumn{6}{|c|}{ Chemical attributes } \\
\hline & \multirow{2}{*}{$\frac{\mathrm{pH}}{\left(\mathrm{H}_{2} \mathrm{O}\right)}$} & $\mathrm{Ca}^{++}$ & $\mathrm{Mg}^{++}$ & $\mathrm{K}^{+}$ & $\mathrm{Al}^{+++}$ & $\mathrm{H}^{+}+\mathrm{Al}^{+++}$ \\
\hline & & \multicolumn{5}{|c|}{ cmolc kg ${ }^{-1}$} \\
\hline TQRB & $7.37^{\mathrm{a}}$ & $8.49^{a}$ & $1.14^{\mathrm{a}}$ & $0.67^{\mathrm{a}}$ & $0.00^{\mathrm{b}}$ & $0.66^{\mathrm{b}}$ \\
\hline TQCL & $5.82^{\mathrm{b}}$ & $1.84^{\mathrm{b}}$ & $0.65^{\mathrm{b}}$ & $1.10^{\mathrm{a}}$ & $1.06^{\mathrm{b}}$ & $4.73^{\mathrm{b}}$ \\
\hline TPS & $5.64^{b}$ & $4.45^{\mathrm{ab}}$ & $0.55^{\mathrm{bc}}$ & $0.23^{\mathrm{a}}$ & $0.40^{\mathrm{b}}$ & $2.33^{\mathrm{b}}$ \\
\hline LAF & $4.23^{\mathrm{C}}$ & $0.07^{\mathrm{b}}$ & $0.13^{\mathrm{c}}$ & $0.29^{\mathrm{a}}$ & $3.21^{\mathrm{a}}$ & $10.35^{\mathrm{a}}$ \\
\hline
\end{tabular}

Means followed by the same letter in a column do not differ based on Tukey's test, $5 \%$.

$\left(\mathrm{H}^{+}+\mathrm{Al}^{+++}, 0.66\right)$ were noted in the TQRB soil, whereas reduced $\mathrm{pH}_{(\mathrm{H} 2 \mathrm{O})}$ values (4.23) and increased exchangeable acidity $\left(\mathrm{Al}^{3+}, 3.21\right)$ and potential acidity $\left(\mathrm{H}^{+}\right.$ $\left.+\mathrm{Al}^{+++}, 10.35\right)$ were found in the soils collected on LAF. Working with burnt earth samples, Steiner et al. (2009) reported similar results to exchangeable acidity $\left(\mathrm{Al}^{3+}\right.$, 0.06 ); however, considerably increased potential acidity values $\left(\mathrm{H}^{+}+\mathrm{Al}^{++}, 10.31\right)$ were noted. These results corroborate the highly positive effects of the burnt earth process on soil fertility amelioration and thus plant nutrition in these environments (Figure 2b). The samples collected from AD under Rubber Plantation (TPS) exhibited moderate active acidity index (5.64), whereas exchangeable acidity $(0.40)$ and potential acidity (2.33) were reduced (Table 3 ).

\section{Carbon, nitrogen, phosphorus and carbon/nitrogen rate}

Sánchez and Cochrane (1980) reported that the main limitations of fertility of Amazonian soils include high acidity, $\mathrm{P}$ deficiency, low cation exchange capacity, N, K, $\mathrm{S}, \mathrm{Ca}, \mathrm{Mg}, \mathrm{Cu}$ and $\mathrm{Zn}$ deficiency, and the high capacity of these soils to fix $P$ applied as a fertilizer. The results achieved in this study revealed large variability in the total carbon (twofold), nitrogen (twofold) and phosphorus (thirtyfold) contents in the different studied areas. The TQRB exhibited the highest values of carbon and nitrogen followed by the LAF, whereas the TPS exhibited the lowest values of these attributes (Table 4).

These results are related to the different soil use management techniques that each site received in recent decades. The high amounts of carbon and nitrogen found in LAF may be the result of the use of fire during the process of slash-and-burn in the primary forest and management of the secondary forest after fallow. Originally burnt earth areas in Amazonia were covered by primary forest. They were cut down, burned and used for grazing. After pasture degradation, they were abandoned and regenerated naturally with secondary forest which is currently more than 100 years old. Large amount of 
Table 4. Soil chemical attributes sampled from a 0 - to $20-\mathrm{cm}$ depth of the of Ramal do Banco Burnt Earth (TQRB), Laranjal Cost Burnt Earth (TQCL), Oxisol under forest (LAF) and Amazonian Dark Earth under Rubber Plantation (TPS) (N=5).

\begin{tabular}{|c|c|c|c|c|c|c|}
\hline \multirow{3}{*}{ Site } & \multicolumn{6}{|c|}{ Chemical attributes } \\
\hline & $\mathbf{P}$ & $\mathrm{Fe}$ & $\mathbf{Z n}$ & $\mathbf{M n}$ & C & $\mathbf{N}$ \\
\hline & \multicolumn{4}{|c|}{$\mathrm{mg} \mathrm{kg}^{-1}$} & \multicolumn{2}{|c|}{$\mathrm{g} \mathrm{kg}^{-1}$} \\
\hline TQRB & $115.05^{a}$ & $13.86^{b}$ & $47.52^{a}$ & $33.56^{\mathrm{a}}$ & $51.75^{a}$ & $3.23^{a}$ \\
\hline TQCL & $60.89^{a b}$ & $37.62^{\mathrm{a}}$ & $6.80^{\mathrm{a}}$ & $12.94^{\mathrm{ab}}$ & $28.86^{b}$ & $1.85^{b}$ \\
\hline TPS & $63.60^{\mathrm{ab}}$ & $8.54^{b}$ & $5.02^{\mathrm{a}}$ & $17.24^{\mathrm{ab}}$ & $23.50^{\mathrm{b}}$ & $1.69^{b}$ \\
\hline LAF & $4.07^{\mathrm{b}}$ & $20.36^{b}$ & $0.88^{\mathrm{a}}$ & $1.56^{\mathrm{b}}$ & $40.74^{a}$ & $2.53^{\mathrm{ab}}$ \\
\hline
\end{tabular}

carbon and nitrogen have been accumulated in this environment from the burning of primary forest plus organic matter from the secondary forest, such as branches, leaves, seeds, etc. On the other hand, burnt earth sites received an extremely high input of animal and vegetable residues from anthropogenic activity, allowing the continue replacement of carbon, nitrogen, phosphorus and others essential nutrients in plant nutrition.

\section{Total base cations (SB), effective cations exchangeable capacity (t), potential cations exchangeable capacity $(T)$, aluminum saturation percentage $(m)$ and base saturation percentage $(V)$}

Comparing the values of chemical attributes ( $\mathrm{SB}, \mathrm{t}$ and $\mathrm{T}$ ) of LAF with the values for TQRB and TPS (Table 5), we observe that $\mathrm{Ca}^{++}, \mathrm{Mg}^{++}$and $\mathrm{K}^{+}$in the TQRB and TPS sites, as well as $\mathrm{H}^{+}+\mathrm{Al}^{3+}$ (potential acidity) in the LAF site (Table 3 ), are the soil attributes that greatly contribute to high values of effective exchangeable cation capacity (t) and potential exchangeable cation capacity $(T)$. These attributes reveal the importance of the "burning process", that is, Burnt Earth "elaboration" process, which increases the liberation of inorganic substances responsible for the release of exchangeable cations and decreases the potential acidity. Thus, the macro and micronutrients are consequently more available for the plant root (Havlin et al., 2013). Base saturation percentage (V) for effective cation exchange capacity is the amount of the exchangeable base cations divided by the soil CEC and multiplied by 100 (expressed as percentage). The low value of this attribute observed for LAF corroborates its results of the SB (total base cations) and $t$ (effective cation exchange capacity), that also indicates low fertility.

\section{Fourier-transform infrared spectroscopy (FTIR)}

FTIR spectra were measured to correlate the chemical bounds of the four groups of soil samples with the chemical attributes presented earlier. Comparing the samples (Figure 3), the spectra exhibited similar characteristics, and the following bands predominated: $\mathrm{OH}$ vibrational modes of kaolinite at $(3700,3650,3621)$ $\mathrm{cm}^{-1}, \mathrm{H}-\mathrm{O}-\mathrm{H}$ stretching mode of adsorbed water at 3430 $\mathrm{cm}^{-1}$, the vibrational modes of $\mathrm{C}-\mathrm{H}$ aliphatic or aromatic at (3100, 2960-2850, 1600, 1385, 750) $\mathrm{cm}^{-1}$, the vibrational modes of the quartz $(\mathrm{Si}-\mathrm{O})$ at $(1100,795,758,695) \mathrm{cm}^{-1}$, kaolinite bending modes $(1035,1005,915,605,470) \mathrm{cm}$ ${ }_{1}$ and Si-O-Al stretching mode at $540 \mathrm{~cm}^{-1}$ (Frost and Vassallo, 1996; Johnston and Aochi, 1996; Tammer, 2004).

The vibrational modes related to the calcium chemical bounds were observed only in the TQRB sample. This result is consistent with the soil chemical attributes wherein the calcium content for this sample was higher than the others.

\section{X-ray photoelectron spectroscopy (XPS)}

Broad survey XPS spectra of the studied soils are presented in Figure 4. From the XPS spectra, the coreelectron binding energies of different elements found in the studied samples can be extracted (Vempati et al., 1996). A variety of elements, such as $\mathrm{Ca}, \mathrm{P}, \mathrm{Al}, \mathrm{Mg}, \mathrm{Si}, \mathrm{S}$ and $\mathrm{Na}$, were observed among other elements that were detected at levels less than $1 \%(\mathrm{~K}, \mathrm{Ti}, \mathrm{Cr}, \mathrm{Mn}, \mathrm{Fe}, \mathrm{Cu}$ and $\mathrm{Zn}$ ). As a general overview, for all soil samples analyzed, the binding energies of the main elements are consistent with those obtained in quartz ( $\mathrm{Si}$ ), metallic oxides (Al, $\mathrm{Ca}$, $\mathrm{P}, \mathrm{Fe}$ ) and metals adsorbed onto clayed materials ( $\mathrm{Mg}$, Ca, P) (Araujo et al., 2014; Archanjo et al., 2014). In particular, $\mathrm{Ca}$ and $\mathrm{P}$ levels were increased in the burnt samples (TQRB and TQCL) compared with LAF and TPS. It is believed that the combustion process in TQ samples may render $\mathrm{Ca}$ and $\mathrm{P}$ compounds more detectable due to the elimination of volatile and low molecular weight compounds.

A detailed high-resolution XPS analysis of the chemical groups in the TPS, TQ and LAF samples is presented in Figure 5 . The $\mathrm{O}$ 1s peak mainly exhibits $\mathrm{C}-\mathrm{O}(532.8 \mathrm{eV})$, $\mathrm{C}-\mathrm{OH}(531.8 \mathrm{eV})$, Si-O $(530.6 \mathrm{eV})$ and Al-O (528.6 eV) binding energies, wherein the $\mathrm{SiO}$ bond was higher in LAF than TPS and TQ samples that presented the most $\mathrm{C}-\mathrm{O}$ bonds (Figure $5 \mathrm{a}$ ). The electron binding energies of 
Table 5. Soil chemical attributes sampled from a 0- to 20-cm depth of the of Ramal do Banco Burnt Earth (TQRB), Laranjal Cost Burnt Earth (TQCL), Oxisol under forest (LAF) and Amazonian Dark Earth under Rubber Plantation (TPS) (N=5).

\begin{tabular}{|c|c|c|c|c|c|c|}
\hline \multirow{3}{*}{ Site } & \multicolumn{6}{|c|}{ Chemical attributes } \\
\hline & \multirow{2}{*}{$\mathrm{C} / \mathrm{N}$} & $\mathrm{SB}^{(\mathrm{a})}$ & $t^{(b)}$ & $\mathbf{T}^{(\mathrm{c})}$ & $m^{(d)}$ & $\mathbf{V}^{(\mathrm{e})}$ \\
\hline & & \multicolumn{3}{|c|}{$\mathrm{cmolc} \mathrm{kg}^{-1}$} & \multicolumn{2}{|c|}{$\%$} \\
\hline TQRB & $16.68^{a}$ & $10.31^{a}$ & $10.31^{a}$ & $10.66^{a}$ & $0.00^{b}$ & $100.00^{a}$ \\
\hline TQCL & $15.68^{a}$ & $3.59^{b}$ & $4.66^{b}$ & $8.32^{a}$ & $30.78^{b}$ & $69.22^{a}$ \\
\hline TPS & $13.93^{\mathrm{a}}$ & $5.23^{a b}$ & $5.63^{\mathrm{ab}}$ & $7.55^{\mathrm{a}}$ & $12.68^{b}$ & $87.32^{a}$ \\
\hline LAF & $16.01^{a}$ & $0.49^{b}$ & $3.71^{\mathrm{b}}$ & $10.84^{\mathrm{a}}$ & $86.63^{a}$ & $13.37^{b}$ \\
\hline
\end{tabular}

${ }^{\mathrm{a}} \mathrm{SB}$ : total base cations $(\mathrm{K}, \mathrm{C}$ and $\mathrm{Mg}) .{ }^{\mathrm{b}} \mathrm{t}$ : effective cation exchange capacity (sum of $\mathrm{K}^{+}, \mathrm{Ca}^{++}, \mathrm{Mg}^{++}$and $\mathrm{Al}^{+++}$). ${ }^{\mathrm{c}} \mathrm{T}$ : potential cation exchange capacity (sum of $\mathrm{K}^{+}, \mathrm{Ca}^{++}, \mathrm{Mg}++, \mathrm{Al}^{+++}$and $\mathrm{H}^{+}+\mathrm{Al}^{+++}$). ${ }^{d} \mathrm{~m}$ : Al saturation percentage for effective cation exchange capacity. ${ }^{\circ} \mathrm{V}$ : base saturation percentage for effective cation exchange capacity.

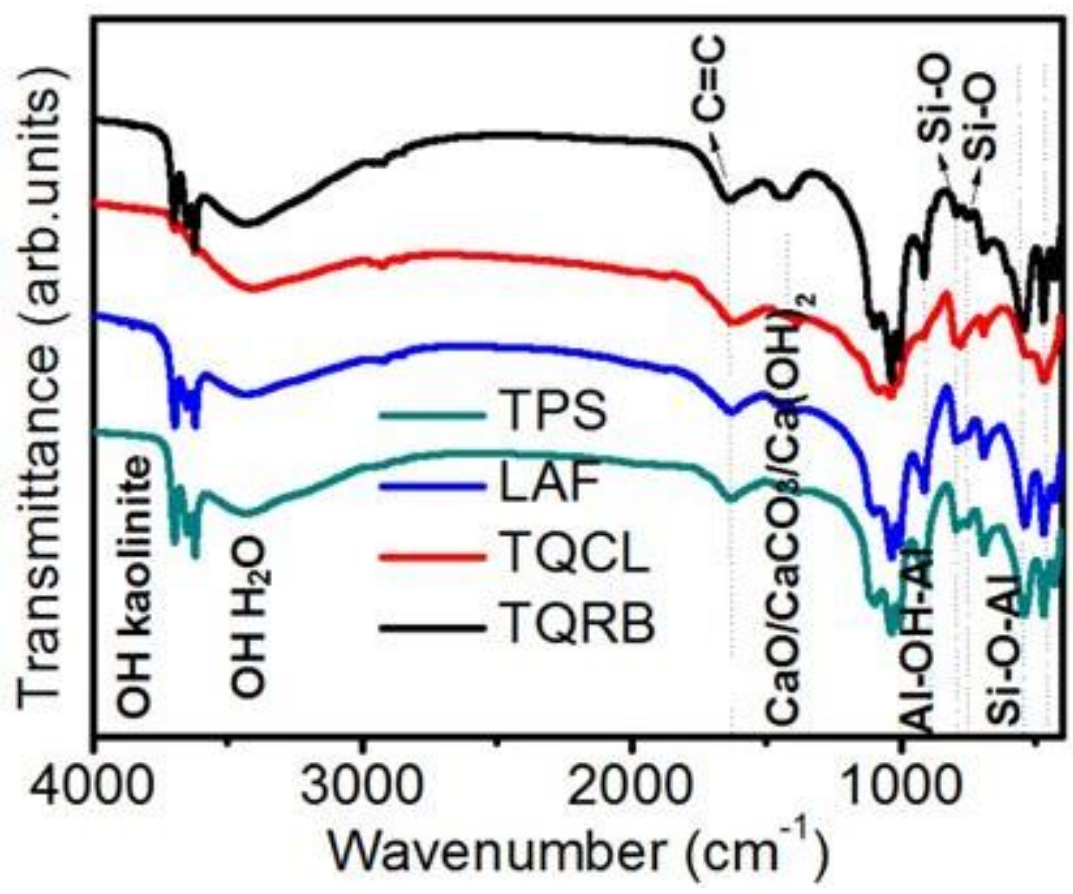

Figure 3. a) FTIR spectra for the four analyzed soil samples: TQRB, TQCL, LAF and TPS. b) FTIR spectra of species typically found in anthropic soil samples, such as hydroxyapatite, kaolinite, calcium oxide, calcium hydroxide, calcium carbonate and a carbon-rich grain of not-burned Terra Preta of Laranjal Cost.

carbon 1s (Figure 5b) are assigned to the functional groups typically found in soil organic carbon, that is, delocalized $\mathrm{sp}^{2}$ hybridized carbon $(\mathrm{C}=\mathrm{C}, 284.1 \mathrm{eV})$, aliphatic carbon (C-C or $\mathrm{C}-\mathrm{H}, 285.0 \mathrm{eV}$ ), unresolved epoxide or hydroxyl (C-O-C and $\mathrm{C}-\mathrm{OH}, 286.1 \mathrm{eV})$, carbonyl $(\mathrm{C}=\mathrm{O}, 287.1 \mathrm{eV}$ ) and carboxylate anion $\left(\mathrm{COO}^{-}, 289.1 \mathrm{eV}\right)$. The four soil samples analyzed exhibited these five components, but the TPS sample revealed higher oxidized carbon groups $(\mathrm{C}-\mathrm{O}, \mathrm{C}=\mathrm{O}, \mathrm{COO})$, which is characteristic of $\mathrm{AD}$ soils (Araujo et al., 2014; Archanjo et al., 2014). Si 2p (Fig. 5c) shows $\mathrm{Si}-\mathrm{O}$ bonds in $103 \mathrm{eV}$, that are typically of quartz form, and silicon nitride $\left(\mathrm{Si}_{3} \mathrm{~N}_{4}\right)$ in $101.7 \mathrm{eV}$ (Tab. 6). Al $2 \mathrm{p}$ peak $(74.5 \mathrm{eV}$ ) depicts binding energies of $\mathrm{Al}-\mathrm{O}$ and $\mathrm{Al}-$ $\mathrm{OH}$ bonds (Figure $5 \mathrm{~d}$ ). In the work developed by Freitas et al. (2000) reported thermal transformations taking place on two kinds of biomass (rice hulls and endocarp of babassu coconut) producing silicon carbide (SiC), silicon nitride $\left(\mathrm{Si}_{3} \mathrm{~N}_{4}\right)$ and high-purity silica, through their thermal decomposition. Although $\mathrm{Si}_{3} \mathrm{~N}_{4}$ binding energy be present in all samples, $\mathrm{SiC}$ and metallic Si binding energies are near to this region, $102 \mathrm{eV}$ and $99.4 \mathrm{eV}$, respectively, then $\mathrm{Si} 2 p$ analysis by itself is not conclusive. We then 


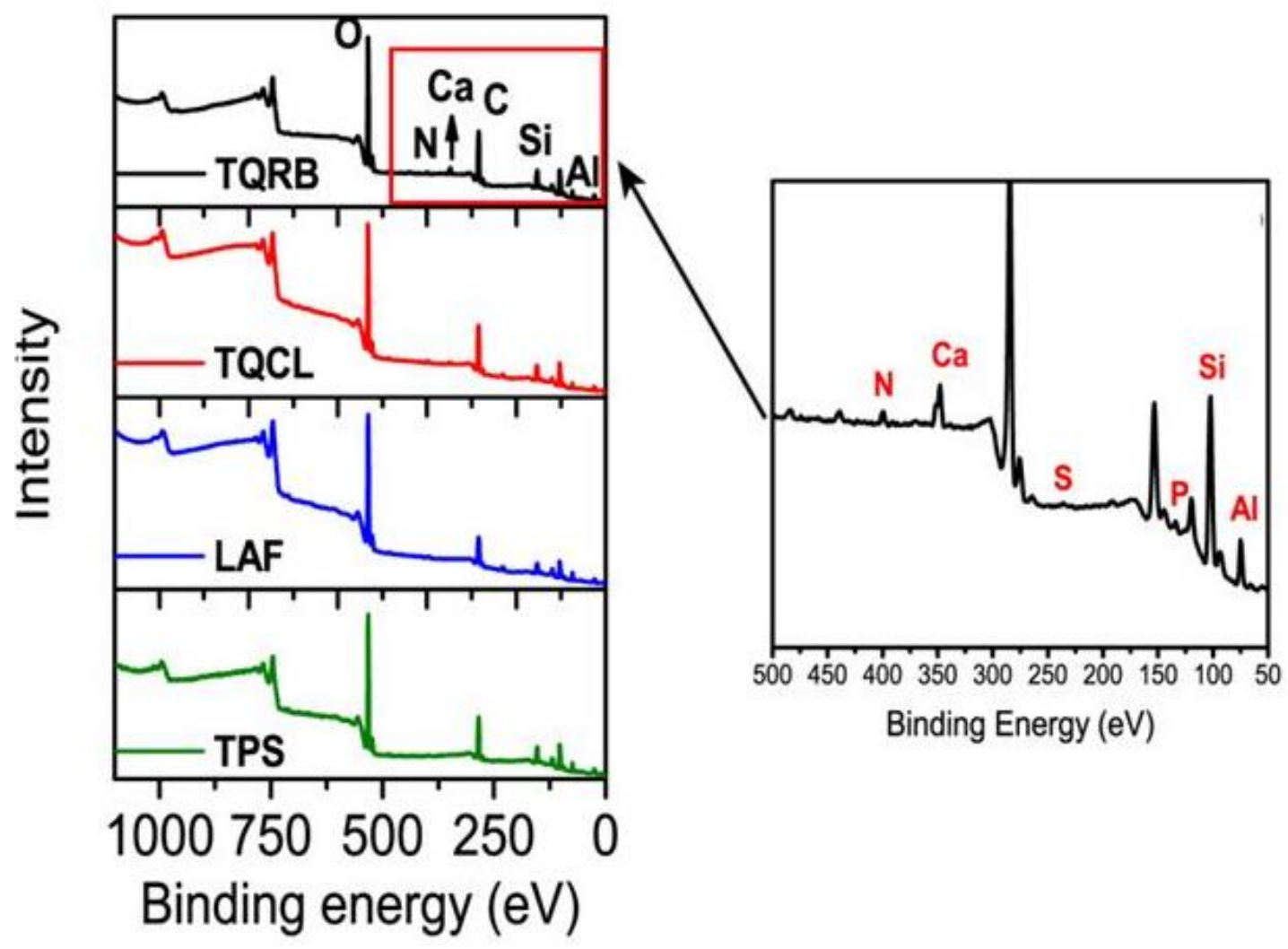

Figure 4. XPS survey spectra depicting TQRB, TQCL, LAF and TPS (from top to bottom). A higher resolution image of the TQRB sample in the 50 to $500 \mathrm{eV}$ region is presented to the right.
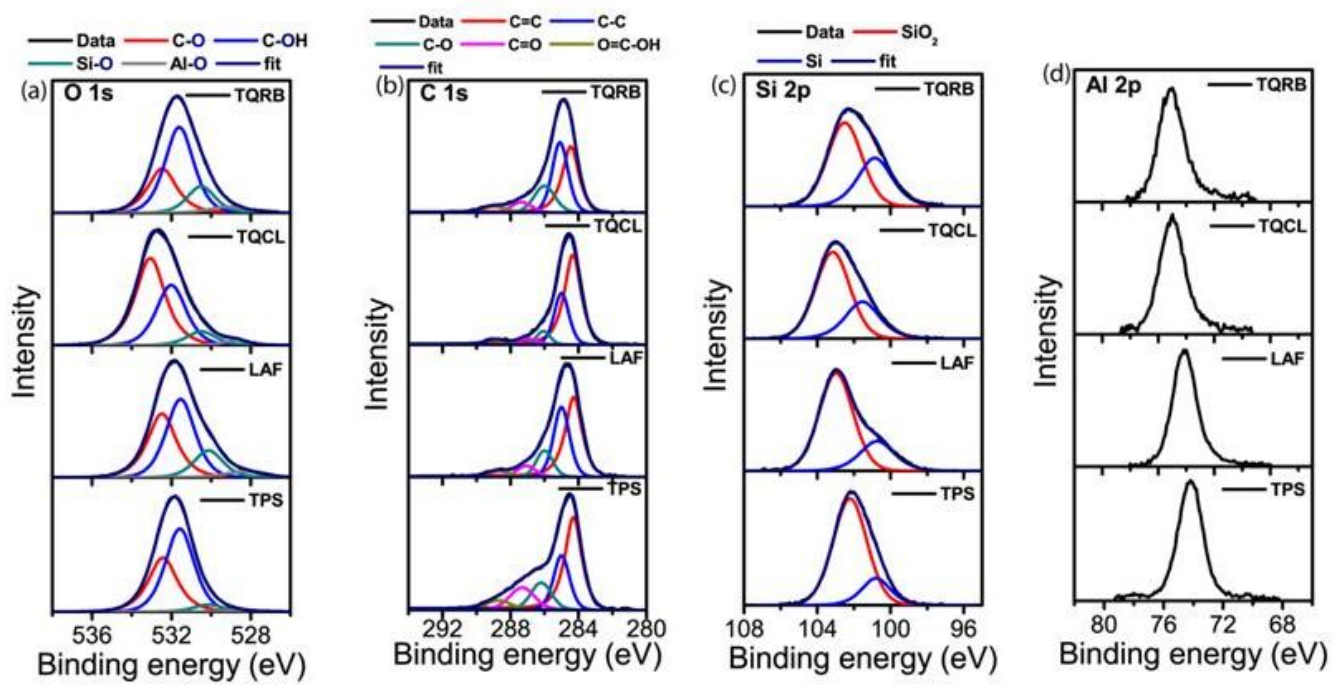

Figure 5. XPS O 1s (a), C 1s (b), Si 2p (c), and Al 2p (d) of the chemical environments for the analyzed soil samples.

analyzed the XPS peaks associated with calcium ( $\mathrm{Ca}$ $2 p)$, nitrogen (N 1s) and phosphorous ( $P 2 p)$ in the TQ soils in detail. Figs 6aand $6 \mathrm{~b}$ indicate that the $\mathrm{Ca} 2 \mathrm{p}$ peak in TQ exhibits a maximum of $347.6 \mathrm{eV}$, and this binding energy is characteristic of calcium phosphates. However, this peak is broad, indicating that other species, such as calcium hydroxides $(\sim 346 \mathrm{eV})$ and calcium carbonates $(346.8 \mathrm{eV})$, are present. This result corroborates results from the chemical attributes analysis and FTIR presented earlier. The nitrogen groups (Figure $6 c$ and $d$ ) were 

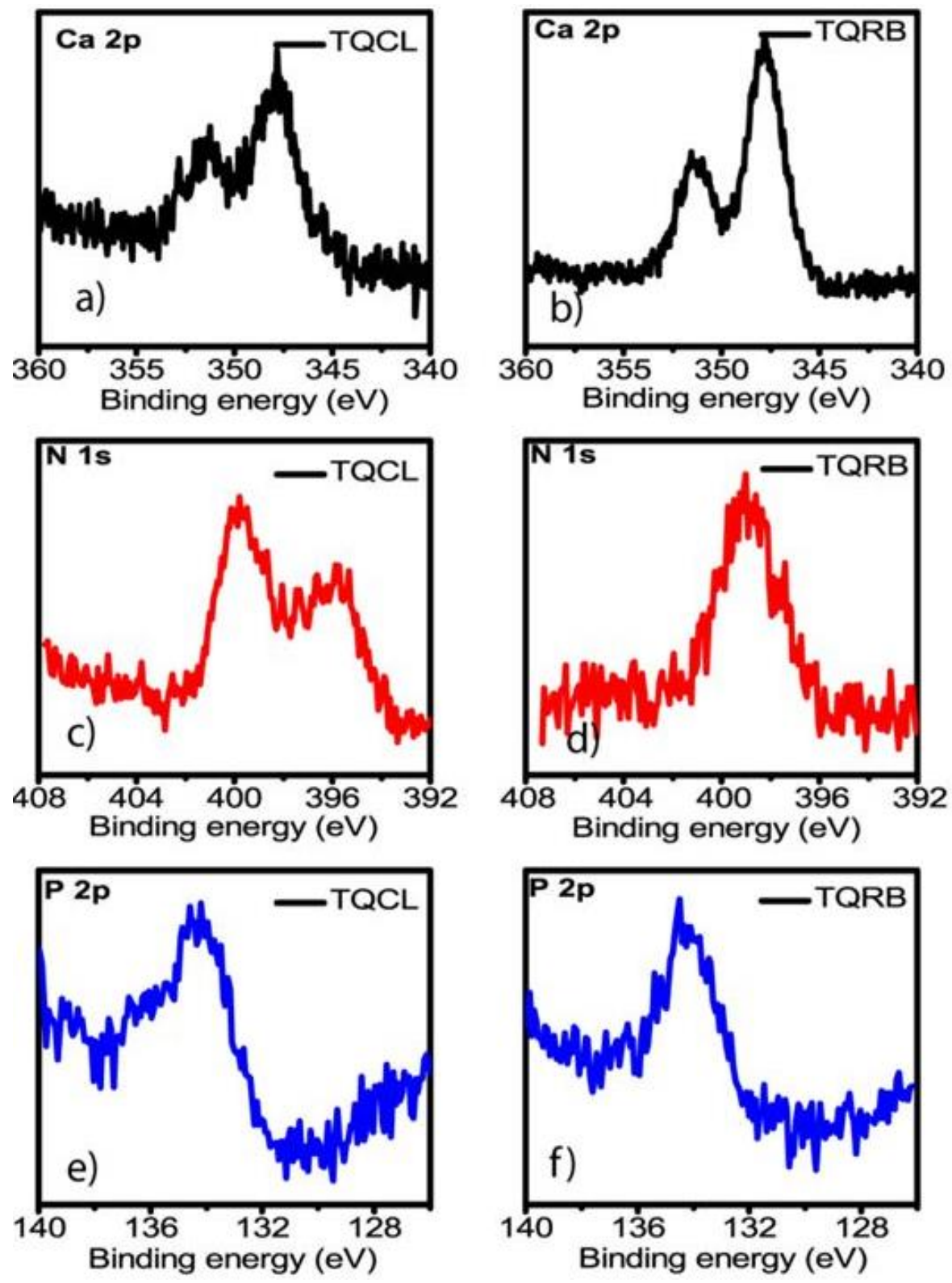

Figure 6. XPS high-resolution spectra collected in $\mathrm{Ca} 2 \mathrm{p}, \mathrm{N}$ 1s and $\mathrm{P} 2 \mathrm{p}$ regions for TQCL (a, c, and e) and TQRB (b, d, and f).

detected mostly in TQ soils. The difference observed was that TQCL and TQRB exhibited two nitrogen forms: one at $399.9 \mathrm{eV}$ (silanamine) and the other at binding energy $<397 \mathrm{eV}$ (metal nitrides) (Table 6). Then, the analyses of $\mathrm{N}$ 1s and Si 2p XPS peaks corroborate the presence of silicon nitrides in TQ's samples. The $P$ binding energy (Figs 6d and 6e) observed for TQCL and TQRB was $134.2 \mathrm{eV}$, indicating the existence of phosphate groups (Araujo et al., 2014; Archanjo et al., 2014). The presence of the above-mentioned chemical groups, mainly $\mathrm{Ca}, \mathrm{P}$, O groups, organically bound silicon species and silicon nitrides, indicate similarity at the molecular level between the $A D$ and $T Q$ soils.

\section{Raman spectroscopy}

The Raman spectra of $\mathrm{sp}^{2}$ carbon materials are simple in general. A band at $\sim 1580 \mathrm{~cm}^{-1}$, known as the $G$ band, is always present, and this band is related to the in-plane $\mathrm{C}=\mathrm{C}$ stretching mode. When some disorder is present in the material, a band at $\sim 1350 \mathrm{~cm}^{-1}$, known as the $D$ (from disorder/defect) band, is also noted. Figure 7a presents a typical Raman spectrum of a carbon particle found in an $A D$ after the baseline subtraction. The intensity ratio $I(D) / I(G)$ of these bands are commonly used as a measure of disorder in many $\mathrm{sp}^{2}$ carbon system, such as the crystallite size (Tuinstra and Koenig, 
Table 6. Summary of XPS peak binding energies $(\mathrm{eV})$ and its respective chemical state observed for the studied soil samples.

\begin{tabular}{|c|c|c|c|}
\hline Element & Binding energy (eV) & Chemical state & Samples \\
\hline $\mathrm{Al}(\mathrm{Al} 2 \mathrm{p})$ & $74.6-74.9$ & $\mathrm{Al}-\mathrm{O} / \mathrm{Al}(\mathrm{OH})_{3}$ & LAF, TPS, TQCL, TQRB \\
\hline \multirow{2}{*}{ Si (Si 2p) } & 103.5 & $\mathrm{SiO}_{2}$ & LAF, TPS, TQCL, TQRB \\
\hline & 101.7 & $\mathrm{Si}_{3} \mathrm{~N}_{4}$ & LAF, TPS, TQCL, TQRB \\
\hline \multirow{3}{*}{ Ca (Ca 2p) } & 347.7 & $\mathrm{Ca}_{3}\left(\mathrm{PO}_{4}\right)_{2}$ & TQCL, TQRB \\
\hline & 346.5 & $\mathrm{CaCO}_{3}$ & TQCL, TQRB \\
\hline & 345.4 & $\mathrm{CaO}$ & TQCL, TQRB \\
\hline \multirow{3}{*}{$N(N$ 1s) } & 399.9 & $\mathrm{NSi}_{2} \mathrm{O}$ & TQCL, TQRB \\
\hline & 397 & Metal Nitrides & TQCL \\
\hline & 397.4 & $\mathrm{NSi}_{3}\left(\mathrm{Si}_{3} \mathrm{~N}_{4}\right)$ & TQCL, TQRB \\
\hline \multirow{5}{*}{$C(C$ 1s) } & 284.1 & $\mathrm{C}=\mathrm{C}$ & LAF, TPS, TQCL, TQRB \\
\hline & 285.0 & $\mathrm{C}-\mathrm{C} / \mathrm{C}-\mathrm{H}$ & LAF, TPS, TQCL, TQRB \\
\hline & 286.1 & $\mathrm{C}-\mathrm{O}-\mathrm{C} / \mathrm{C}-\mathrm{OH}$ & LAF, TPS, TQCL, TQRB \\
\hline & 287.1 & $\mathrm{C}=\mathrm{O}$ & LAF, TPS, TQCL, TQRB \\
\hline & 289.1 & $\mathrm{COOH}$ & LAF, TPS, TQCL, TQRB \\
\hline \multirow{3}{*}{$\mathrm{O}(\mathrm{O}$ 1s) } & 530.6 & O-Si & LAF, TPS, TQCL, TQRB \\
\hline & 531.8 & $\mathrm{OH}-\mathrm{C}$ & LAF, TPS, TQCL, TQRB \\
\hline & 532.8 & $\mathrm{O}-\mathrm{C}$ & LAF, TPS, TQCL, TQRB \\
\hline
\end{tabular}
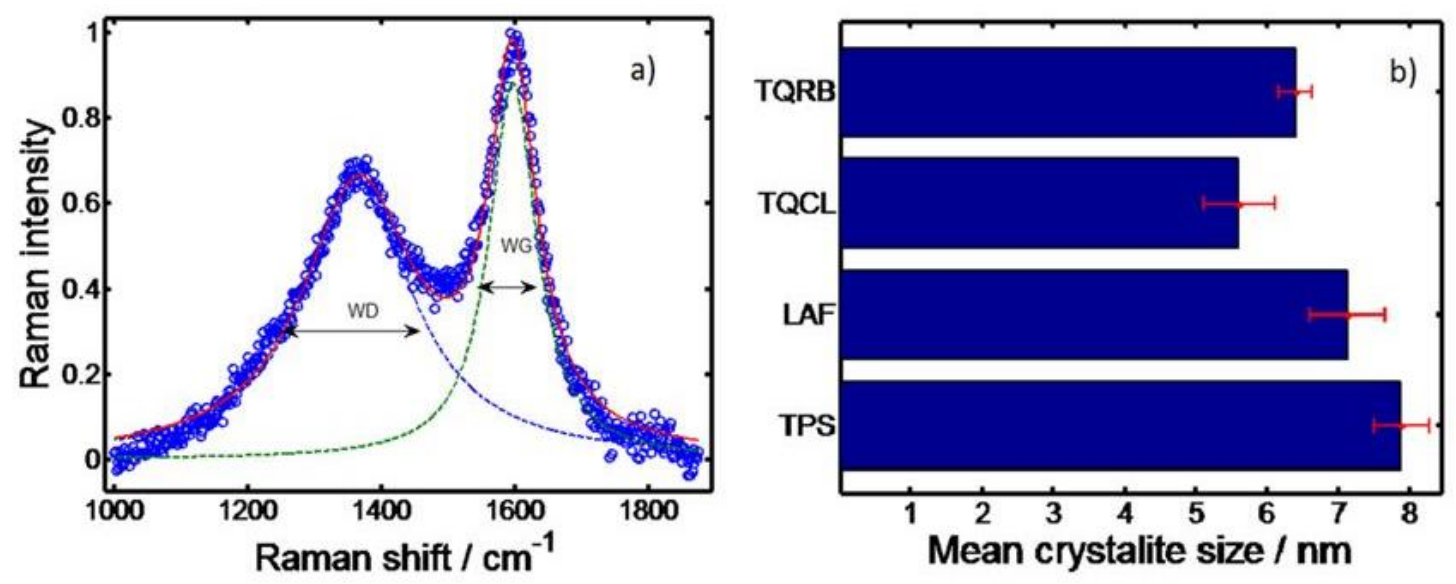

Figure 7. (a) Typical Raman spectrum of a carbon particle found in the TPI/TQ samples. The figure shows the two most prominent bands: $D$ and $G$. (b) Average mean crystallite size of the carbon particles as calculated using Equation 1.

1970) or density of defects (Martins Ferreira et al., 2010). However, in some cases, it is more useful to consider the width of the bands. As Ribeiro-Soares (Ribeiro-Soares et al., 2013) recently demonstrated for some $A D$ soils, a relation exists between the $G$ band width $\left(W_{G}\right)$ and the mean crystallite size $\left(L_{a}\right)$ of the carbon particles in the soil, as given by the following formula:

$$
L_{a}[\mathrm{~nm}]=\frac{496}{W_{G}\left[\mathrm{~cm}^{-1}\right]-15}
$$

In Figure 7b, we plot the average mean crystallite size calculated for the different soils. Only a small difference is noted in the carbon nanostructure of the different soils. 
All samples present a small $L_{a}$ between $5 \mathrm{~nm}$ and $8 \mathrm{~nm}$, which is consistent with the previous finding for $A D$ soils (Ribeiro-Soares et al., 2013). In comparison, laboratory produced charcoal has typically a $L_{a}>10 \mathrm{~nm}$. Among the studied soils, TQRB and TQCL present smaller values of $L_{a}$ as well as better fertility parameters. This evidence suggests that the carbon crystallite size is an important parameter for soil stability, as argued by Jorio et al. (2012) and Archanjo et al. (2014).

\section{CONCLUSION}

TQRB exhibited a significantly higher $\mathrm{pH}$ as well as $\mathrm{C}, \mathrm{N}$, $\mathrm{P}, \mathrm{Ca}, \mathrm{Mg}, \mathrm{Zn}$ and $\mathrm{Mn}$ availability compared with other studied sites, corroborating the highly positive effects of the burnt earth process for soil fertility amelioration. The superiority of TQRB fertility compared with other soils is directly related to high amounts of pyrogenic carbon and exchangeable calcium from the carbonated substances, both of which are produced during this non-homogenous low-temperature combustion process.

Homegarden cultivation is a technique that has already been used by small producers in the Amazon and that can be further improved. For this reason, we need to strengthen this line of research, defining best methods of collecting field data, probably working together with small farmers. Despite the data collection, new agricultural methods of management can be tested by applying the knowledge acquired in the materials science field concerning organo-mineral interaction models aiming maintenance and improvement on the soil fertility. Given the size of the Amazon, the number of small producers around this region, and especially the lack of agricultural technologies adapted to regional conditions, the burnt earth production process can be considered as an alternative for these producers to ensure food production.

\section{ACKNOWLEDGEMENTS}

This work was supported by Inmetro, Inpa, Fapeam, FAPERJ and CNPq.

\section{REFERENCES}

Antal MJ, Grønli M, 2003. The art, science, and technology of charcoal production. Indust Eng Chem Res, 42: 1619-1640.

Araujo J, Archanjo B, de Souza K, Kwapinski W, Falcão NS, Novotny $E$, Achete C, 2014. Selective extraction of humic acids from an anthropogenic Amazonian dark earth and from a chemically oxidized charcoal. Biol Fertil Soils, 50: 1223-1232.

Archanjo BS, Araujo JR, Silva AM, Capaz RB, Falcão NPS, Jorio A, Achete CA, 2014. Chemical analysis and molecular models for calcium-oxygen-carbon interactions in black carbon found in fertile Amazonian anthrosoils. Environ Sci Technol, 48: 7445-7452.

Archanjo BS, Baptista DL, Sena LA, Cancado LG, Falcao NPS, Jorio A, Achete CA, 2015. Nanoscale mapping of carbon oxidation in pyrogenic black carbon from ancient Amazonian anthrosols. Environ Sci-Process Impacts, 17: 775-779.
Baillie IC, 2001. Soil Survey Staff 1999, Soil Taxonomy. Soil Use Manag, 17: 57-60.

Brady NC, Weil RR, 1999. The Nature and Properties of Soils. Prentice Hall.

De Souza Falcão N, Comerford N, Lehmann J, 2003. Determining Nutrient Bioavailability of Amazonian Dark Earth Solis Methodological Challenges. In: Lehmann J, Kern D, Glaser B, Wodos W (eds) Amazonian Dark Earths, Springer Netherlands, pp 255-270.

Denevan W, 2004. Semi-Intensive Pre-European Cultivation and the Origins of Anthropogenic Dark Earths in Amazonia. In: Glaser B, Woods W (eds) Amazonian Dark Earths: Explorations in Space and Time, Springer Berlin Heidelberg, pp 135-143.

Doumer ME, Arízaga GGC, Silva DAd, Yamamoto $\mathrm{Cl}$, Novotny EH, Santos JM, Santos LOd, Wisniewski Jr A, Andrade JBd, Mangrich AS, 2015. Slow pyrolysis of different Brazilian waste biomasses as sources of soil conditioners and energy, and for environmental protection. J Anal Appl Pyrolysis, 113: 434-443.

EMBRAPA, 1999. Manual de Análises Químicas de Solos, Plantas e Fertilizantes, EMBRAPA Solos, Rio de Janeiro, Brazil

EMBRAPA, 2006. Sistema brasileiro de classificação de solos, second ed. EMBRAPA Solos, Rio de Janeiro, Brazil

Falcão NPS, Silva JRAd, 2004. Características de adsorção de fósforo em alguns solos da Amazônia Central. Acta Amazonica, 34: 337-342.

Falcão NPS, Moreira A, Comeford NB, 2010. A fertilidade dos solos de terra preta de índio da Amazônia Central. In: Teixeira, W.G. (org.). As terras Pretas de Índio da Amazônia: Sua Caracterização e Uso deste Conhecimento na Criação de Novas Áreas. 1ed. Rio de Janeiro: EMBRAPA.

FAO, 1994. Soil map of the world. Technical Paper 20. Reprint of World Soil Resources Report 60, FAO, Rome, 1988. Reprint with corrections, 1990. ISRIC, Wageningen, Netherlands.

Fernandes ECM, Nair PKR, 1986. An evaluation of the structure and function of tropical homegardens. Agric Syst, 21: 279-310.

Freitas JCC, Emmerich FG, Bonagamba TJ, 2000. High-resolution solid-state NMR study of the occurrence and thermal transformations of silicon-containing species in biomass materials. Chem Mater, 12: 711-718.

Frost RL, Vassallo AM, 1996. The dehydroxylation of the kaolinite clay minerals using infrared emission spectroscopy. Clays Clay Minerals, 44: 635-651.

Gibbon D, 2007. Tropical Homegardens: A Time-Tested Example of Sustainable Forestry. Springer Series: Advances in Agroforestry. Vol. 3. Edited by B. M. Kumar and P. K. R. Nair. Dordrecht, The Netherlands: Springer (2006), pp. 377, £107.50. ISBN-10: 1-40204947-1. Exper Agric, 43: 263-263.

Glaser B, Guggenberger G, Zech W, 2004. Identifying the PreColumbian Anthropogenic Input on Present Soil Properties of Amazonian Dark Earths (Terra Preta). In: Glaser B, Woods W (eds) Amazonian Dark Earths: Explorations in Space and Time, Springer Berlin Heidelberg, pp 145-158.

Griffith DM, 2000. Agroforestry: A refuge for tropical biodiversity after fire. Conserv Biol, 14: 325-326.

Havlin J, Tisdale SL, Nelson WL, Beaton JD, 2013. Soil Fertility and Fertilizers: An Introduction to Nutrient Management. Pearson.

Johnston CT, Aochi YO, 1996. Fourier Transform Infrared and Raman Spectroscopy. In: Sparks DL, Page AL, Helmke PA, Loeppert RH (eds) Methods of Soil Analysis Part 3-Chemical Methods, Soil Science Society of America, American Society of Agronomy, Madison, WI, pp 269-321.

Jorio A, Ribeiro-Soares J, Cançado LG, Falcão NPS, Dos Santos HF, Baptista DL, Martins Ferreira EH, Archanjo BS, Achete CA, 2012. Microscopy and spectroscopy analysis of carbon nanostructures in highly fertile Amazonian anthrosoils. Soil Till Res, 122: 61-66.

Klüpfel L, Keiluweit M, Kleber M, Sander M, 2014. Redox properties of plant biomass-derived black carbon (biochar). Environ Sci Technol, 48: 5601-5611.

Kuo S, 1996. Phosphorus. In: Sparks DL, Page AL, Helmke PA, Loeppert RH (eds) Methods of Soil Analysis Part 3-Chemical Methods, Soil Science Society of America, American Society of Agronomy, Madison, WI, pp 869-919.

Lilley DG, 1999. Fire dynamics - A primer. J Propulsion Power, 15: 204-215. 
Malavolta E, 1976. Manual de química agrícola: Nutriçao de plantas e fertilidade do solo. Agronômica Ceres.

Martins Ferreira EH, Moutinho MVO, Stavale F, Lucchese MM, Capaz $\mathrm{RB}$, Achete $\mathrm{CA}$, Jorio A, 2010. Evolution of the Raman spectra from single-, few-, and many-layer graphene with increasing disorder. Phys Rev B, 82: 125429.

Miller RP, Penn JW Jr., van Leeuwen J, 2006. Amazonian homegardens: Their ethnohistory and potential contribution to agroforestry development. In: Kumar BM, Nair PKR (eds) Tropical Homegardens, Springer Netherlands, pp 43-60.

Montagnini F, 2006. Homegardens of Mesoamerica: Biodiversity, food security, and nutrient management. In: Kumar BM, Nair PKR (eds) Tropical Homegardens, Springer Netherlands, pp 61-84.

Nelson DW, Sommers LE, 1996. Total Carbon, Organic Carbon, and Organic Matter. In: Sparks DL, Page AL, Helmke PA, Loeppert RH (eds) Methods of Soil Analysis Part 3-Chemical Methods, Soil Science Society of America, American Society of Agronomy, Madison, WI, pp 961-1010.

Neves E, Petersen J, Bartone R, Heckenberger M, 2004. The Timing of Terra Preta Formation in the Central Amazon: Archaeological Data from Three Sites. In: Glaser B, Woods W (eds) Amazonian Dark Earths: Explorations in Space and Time, Springer Berlin Heidelberg, pp 125-134.

Pagano MC, Ribeiro-Soares J, Cancado LG, Falcao NPS, Goncalves VN, Rosa LH, Takahashi JA, Achete CA, Jorio A, 2016. Depth dependence of black carbon structure, elemental and microbiological composition in anthropic Amazonian dark soil. Soil Till Res, 155: 298307.

Ratisbona L, 1976. The climate of Brazil. Climates of Central and South America, 12, 219-293.

$R$ Development Core Team, 2008. R: A language and environment for statistical computing. R Foundation for Statistical Computing, Vienna.

Ribeiro-Soares J, Cançado LG, Falcão NPS, Martins Ferreira EH, Achete CA, Jorio A, 2013. The use of Raman spectroscopy to characterize the carbon materials found in Amazonian anthrosoils. $J$ Raman Spectroscopy, 44: 283-289.

Sánchez PA, 1976. Properties and management of soils in the tropics. Wiley.

Sánchez PA, Cochrane TT, 1980. Soils constraints in relation to major farming systems of tropical America. In: International Rice Research Institute, Los Banos, USA, pp 106-139.

Steiner C, Teixeira WG, Woods WI, Zech W, 2009. Indigenous Knowledge About Terra Preta Formation. In: Woods W, Teixeira W, Lehmann J, Steiner C, WinklerPrins A, Rebellato L (eds) Amazonian Dark Earths: Wim Sombroek's Vision, Springer Netherlands, pp 193204.

Tammer M, 2004. G. Sokrates: Infrared and Raman characteristic group frequencies: tables and charts. Colloid Polym Sci, 283: 235235

Tuinstra F, Koenig JL, 1970. Raman spectrum of graphite. J Chem Phys, 53: 1126-1130.

Turney CSM, Wheeler D, Chivas AR, 2006. Carbon isotope fractionation in wood during carbonization. Geochimica et Cosmochimica Acta, 70: 960-964.
Van Alfen NK, 2014. Encyclopedia of Agriculture and Food Systems: 5volume set. Elsevier Science.

Vempati RK, Hess TR, Cocke DL, 1996. X-Ray Photoelectron Spectroscopy. In: Sparks DL, Page AL, Helmke PA, Loeppert RH (eds) Methods of Soil Analysis Part 3-Chemical Methods, Soil Science Society of America, American Society of Agronomy, Madison, WI, pp 357-375.

Weersum KF, 1982. Tree gardening and taungya on Java: examples of agroforestry techniques in the humid tropics. Agroforestry Syst, 1: 5370.

WinklerPrins AMGA, 2002. House-lot gardens in Santarém, Pará, Brazil: Linking rural with urban. Urban Ecosystems, 6: 43-65.

WinklerPrins AMGA, Souza PSd, 2005. Surviving the city: Urban home gardens and the economy of affection in the Brazilian Amazon. J Latin Am Geogr, 4(1): 107-126.

Citation: Falcão NPS, Lopes ES, Ferreira EHM, Oliveira DM, Archanjo BS, Achete CA, Araujo JR, 2018. Spectroscopic and chemical analysis of burnt earth under Amazonian homegarden systems and anthropic Amazonian dark soils. Net J Agric Sci, 7(1): 1-12. 